tribution of their patronage. A fifth chapter discusses the tastes of listeners and viewers as they emerge when people have a chance to express their views in respect of a range of categories of programme output, and includes a comparison of the tastes of men and women of different age groups and different educational levels. Each chapter ends with a summary of its main findings, but a concluding section of the report entitled "Highlights and Reflections" attempts to view the results as a whole. At the present time there are three distinct publics. The first, 'Band 1/3', which can receive both B.B.C. and Independent television and also sound broadcasting (now about half the population), is gradually swallowing up the other two: 'Band 1', which ean receive B.B.C. television and sound (now about 20 per cent), and the 'sound only', which cannot receive television (now about 30 per cent). About 15 per cent had very high frequency receivers, and three-quarters of these are in television homes. The 'sound only' public is somewhat older and of a slightly higher educational level than the 'sound and television' public, and on average families in this group are a good deal smaller than 'sound and television' families. The 'Band l' public also was somewhat older and of a rather higher educational standard than the 'Band $1 / 3$ ' public.

The typical viewer watches television in winter for approaching two hours each evening, and this means that at peak hours not far short of half the adult population is watching television. The typical listener has his radio on for not much more than half an hour a night and will usually be doing something else at the same time. In television homes sound broadcasting is used very little in the evening, and after 6 p.m. it is catering primarily for people who have no television set. The vast majority of its day-time audiences, particularly in the early morning period and on Sundays, consists of people who have television sets. The inquiry showed that most people exercised their opportunity to choose between different programme services ; those who did so, both viewers and listeners, outnumbering single-service loyalists by about two to one; but those who settled for one service were by no means homogeneous in either choice or tastes. There was an abnormally high proportion of discriminating listeners among those who limit their listening to the Home Service, and an abnormally high proportion of discriminating viewers among those who, though they could view Independent television, rarely did so.

A relation was noted between the amount of time people devote to listening or viewing and the services they patronize. The more time a person spends in listening the greater the proportion of that time he is likely to give to the Light Programme; similarly, the more he views, the greater is likely to be the proportion of his time spent in viewing Independent television. The inquiry showed that the less a person listens or views the more likely he is to be selective, and the more selective he is, the more likely he is to prefer the kinds of programme characteristic of the Home Service and the B.B.C. television than of the Light Programme and Independent television. Again, the older a listener is, the less likely he is to enjoy feature films, crime series, or westerns. Sex is sometimes predictive, women being more likely than men to be 'heavy' consumers of both sound and television in the evening. Science features on television, ranging sixteenth out of eighteen categories in popularity with the public, were not unpopular with men but were unpopular with women and most unpopular with viewers over sixty. Their popularity increases with each step up the educational level, and most often the individual's behaviour, attitudes and tastes tend to be associated with the age when his full-time education ceased, and/or 'occupational status', frequently reinforced by information about the newspapers he reads. Again and again the report demonstrates that the higher the individual's cultural level, the less he tends to listen or view, the more likely he is to be selective and to take an interest in serious types of programmes. Whatever measure of 'cultural level' is used, the population appears as a sharply tapering pyramid, and, accordingly, the more a type of broadcasting output or service depends for its custom upon people who have enjoyed cultural advantages or want something more than the un. demanding relaxation, the more numerically restricted its audience is likely to be. So far as science is concerned the inquiry indicates that nearly all effective viewing is on B.B.C. television and hence anything that prejudices B.B.C. television as against Independent television would be liable to prejudice the use of television in the presentation of science to the public.

\title{
AUTOMATION AND ITS HUMAN REPERCUSSIONS
}

$\mathrm{T}$ HE mental health problems of automation were examined recently by a World Health Organization study group (Study Group on the Mental Health Problems of Automation. (World Health Organization Report, Series No. 183.) Pp. 30. Geneva : W.H.O. ; London : H.M. Stationery Office, 1959). It is not automation in the form of automatic co-ordination of machine tools on production lines, nor in the form of automatic control over manufacturing processes, that is liable to bring about the most revolutionary changes in mechanized work, but the rapid and automatic processing of an increasing range of technical and business information by the electronic digital computer.

Emotional reactions to automation range from unreasonable hopes of a rapid rise in living standards to fears of upheavals in conditions of employment and of difficulty in adaptation to the new machines. These reactions are of an anticipatory nature and are not based on actual experience. In the meantime, workers in automated undertakings are already suffering from physiologieal and psychological strain.

Because of its nature, automated work may have psychological consequences: for example, if the manual activity of a worker who has been accustomed to assess his work on the basis of his physical effort is reduced, he will feel himself less useful and suffer from a sense of inadequacy; if contact with the machine or with the object on which he is working is eliminated or reduced, he will see his task in a more abstract form and this may lead to anxiety; if his 
responsibility is increased his job may become more of a strain.

What kind of strains are imposed upon the worker ? First, there is the nervous strain caused by the need of unremitting attention to signals of varying perceptability, often separated by long intervals. The less the physical activity of such a worker and the greater the number of indicators to be watched, the more the nervous tension to which he will be exposed. In these circumstances particular importance will be attached to working conditions, such as temperature, sound-proofing, lighting, and the position of the operator and the machines. By preventing the operator from communicating with others, automated work tends to isolate him both physically and mentally. This feeling of isolation may be heightened by the background noise made by the machines.

In addition to its direct effects upon the workers' mental health, automation will undoubtedly have indirect social consequences. Families may, for example, be affected by the increased mobility of labour. The most serious difficulties indirectly affecting mental health are, however, liable to arise in connexion with the organization of the work itself. If automation calls for more shift work (as appears likely), this will certainly be opposed by the workers and their families.

Automation may provide certain satisfactions; for example, in an entirely automated plant, each operator becomes more or less his own master; the gap lessens between the factory worker and the office worker, and changes of occupation in middle age should be easier.

Efforts to mitigate the harmful effects of automation on mental health should be based on informa. tion and education. Education will be all the more effective if it is directed primarily towards those in key positions, that is to say, managers, engineers, trade-union leaders and the medical profession, particularly works doctors.

\section{EMPLOYMENT OF WOMEN IN BRITAIN}

$\mathrm{T}$ HE Institute of Personnel Management has published under the title "Working Wives" a survey of facts and opinions concerning the gainful employment of married women in Britain carried out in co-operation with Mass Observation, Ltd., by Viola Klein during the autumn months of 1957, when out of $12,820,000$ married women in Great Britain nearly 4 million were gainfully employed (Occasional Papers, No. 15. Pp. 63 . London: Institute of Personnel Management, 1960. 7s. 6d.). Thus, in about one out of every three households the wife contributes by her earnings to the family income, but the apparent steep rise in the employment of married women since 1951 is due to the Population Census seriously underrating the number of married women in employment, particularly part-time. The outstanding impression gained by the survey is that women's lives to-day are dominated as much as ever by their role-actual or expected-as wives and mothers, and all other occupations are subordinated to their responsibility for home and family. The growth in the number of married women going out to work is due to the smaller size of their families and the general reduction in housework through the modernization of household techniques, combined with a striving to improve their standards of living. It is not widely assumed that married women should have jobs, although among the more highly educated single women in the sample nearly one third wished to continue their careers after marriage ; this is nearly double the percentage in the next occupational group of women willing to continue in employment not merely temporary. The taking up of employment by married women appears to result from unforeseen though not unforeseeable cireumstances, and men appear to be loss conservative in their outlook in these matters than they are usually assumed to be.

Slightly more than one half the married women in employment have part-time jobs, which may be in the region of 4-30 hr. per week. The sample also showed that two-thirds of the women in part-time employment are engaged in unskilled or semi-skilled work, and that shorthand typing is the occupation least likely to offer any scope for the married woman who wishes to supplement her income by part-time employment. In some smaller occupational groups, such as teachers, nurses, social workers, a shortage of trained staff has opened the doors to part-time employees, and though the problems involved have not yet received the attention they deserve, more opportunities may well be offered here in the future for married women to combine a career with having a family. Women, in fact, it is concluded, are an essential and distinctive part of our man-power resources.

\section{EXPLORATIONS OF THE GALÁPAGOS ISLANDS}

$\mathrm{T}$ HE Galápagos Islands have recently attracted widespread attention as a result of the Darwin centenary and the measures at present being taken to preserve and study their flora and fauna. The Galápagos Islands have been one of the principal fields of endeavour of the California Academy of Sciences since its first expedition there during 1905-6, and its collections from the archipelago are unsurpassed. It is therefore appropriate that the Academy should publish a short history of the islands by the late Joseph Richard Slevin, for more than fifty- three years associated with its Department of Herpetology, and a member of the original expedition, who for half a century maintained an active interest in the islands and published a number of scientific and popular papers about them (Occasional Papers of the California Academy of Sciences. No. 25: The Galápagos Islands : a History of their Exploration. By Joseph Richard Slevin. Pp. $x+150$. San Francisco : California Academy of Sciences, 1959).

This publication gives a description of the islands, their geology, climate, and fauna, but it is mainly 